\title{
Circulating serovars of Leptospira in cart horses of central and southern Ethiopia and associated risk factors
}

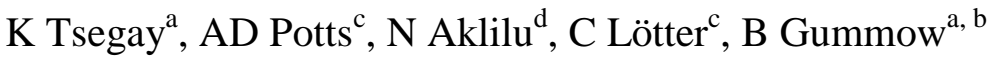 \\ ${ }^{a}$ Discipline of Veterinary Science, James Cook University, Townsville, Queensland, 4811, Australia. Ph 617 \\ 47814071, bruce.gummow@jcu.edu.au
}

${ }^{\mathrm{b}}$ Department of Production Animal Studies, University of Pretoria, Pretoria, South Africa

${ }^{c}$ Agricultural Research Council, Onderstepoort Veterinary Institute, Private Bag X05, Onderstepoort, South Africa

${ }^{\mathrm{d}}$ Society for the Protection of Animals Abroad-Ethiopia project, College of Veterinary Medicine and Agriculture, Addis Ababa University, Bishoftu, Ethiopia

\begin{abstract}
Little work has been done on diseases of horses in Ethiopia or tropical regions of the world. Yet, Ethiopia has the largest horse population in Africa and their horses play a pivotal role in their economy as traction animals. A serological and questionnaire survey was therefore conducted to determine the circulating serovars of Leptospira and their association with potential risk factors in the cart horse population of Central and Southern Ethiopia. A total of 184 out of 418 cart horses from 13 districts had antibody titres of 1:100 or greater to at least one of 16 serovars of Leptospira species in Central and Southern Ethiopian horses. A significantly higher seropositivity $(62.1 \%)$ was noted in horses from the highland agroecology followed by midland (44.4\%) and lowland (39.8\%). Serovar Bratislava (34.5\%) was the predominant serovar followed by serovars Djasiman (9.8\%), Topaz (5.98\%) and Pomona (5.3\%). Age and location proved to be associated with seropositive horses with older horses being more commonly affected and the districts of Ziway (Batu) (Apparent Prevalence
\end{abstract}


$(\mathrm{AP})=65.5 \%)$, Shashemene $(\mathrm{AP}=48.3 \%)$ and Sebeta $(\mathrm{AP}=41.4 \%)$ having the highest prevalence. Multivariable logistic regression found risk factors significantly associated with Leptospira seropositive horses were drinking river water $(\mathrm{OR}=2.8)$ and horses 7-12 years old $(\mathrm{OR}=5)$ and risk factors specifically associated with serovar Bratislava seropositive horses were drinking river water $(\mathrm{OR}=2.5)$, horses $\geq 13$ years $(\mathrm{OR}=3.5)$ and the presence of dogs in adjacent neighbouring properties $(\mathrm{OR}=0.3)$. Dogs had a protective effect against seropositivity to serovars Bratislava and Djasiman, which may be due to their ability to control rodents. The high seroprevalence confirm that leptospirosis is endemic among horses of Central and Southern Ethiopia. The predominance of serovar Bratislava supports the idea that serovar Bratislava may be adapted to and maintained by the horse population of Central and Southern Ethiopia. This study emphasizes the need for further countrywide serological surveys and isolation of circulating leptospires in animals and humans in order to understand the role of horses in the epidemiology of this disease.

Key words: Ethiopia, Cart horse, Leptospira, Leptospirosis, Seroprevalence, Serovar Bratislava, Risk factors

\section{Introduction}

Agriculture is the dominant economy in Ethiopia, with livestock being an essential component (Ayelet et al., 2013). A recent livestock survey in Ethiopia estimates there are about 1.91 million horses, 6.75 million donkeys and 0.35 million mules (CSA, 2013). Previous studies have demonstrated the value of working equidae to communities in developing countries (Pearson and Vall, 1998). The economic and social contributions of equines to the livelihoods of the poor in terms of income, creation of employment opportunities and transportation are enormous (Admassu and Shiferaw, 2011). Transport is 
an important activity of working animals such as horses in marketing products, supporting the household, and in aiding the community where transport services are limited (Pearson and Krecek, 2006). In urban towns in Ethiopia, horse-drawn taxi carts are a source of sustainable income for a significant number of Ethiopian families (Dinka et al., 2007).

The limited literature available shows that leptospirosis is one of the health problems of Ethiopian horses. In a serological survey of domestic and wild animals in 1975, 91.3\% of the 34 sampled horses in Ethiopia were positive for Leptospira, making it more common in horses than other animal species tested at the time (Moch et al., 1975).

Leptospirosis is a widespread zoonotic disease caused by spirochetes belonging to the genus Leptospira and is largely reported worldwide, particularly in tropical countries (Hines, 2007). Although horses are incidental hosts for most serovars of Leptospira, serological surveys around the world showed that leptospirosis occurs frequently in horses and can be caused by a wide variety of Leptospira serovars (Arent and Kedzierska-Mieszkowska, 2013). Studies have indicated that horses tend to be seropositive to different serovars in different parts of the world, Leptospira interrogans serovars Icterohaemorrhagiae, Bratislava, Pomona, Ballum, and Grippotyphosa being the most common in horses (Szeredi and Haake, 2006).

There is a single published study which investigated leptospirosis in domestic and wild animals in Ethiopia in 1975 in which antibodies to serotype Butembo were predominant in sera of the majority of the serologically examined animal species. Serovar Grippotyphosa rather than Butembo was the predominant reacting serotype in camels and dogs (Moch et al., 1975). Since 1975, there have not been any published studies looking at leptospirosis in any animal species in Ethiopia. The climatologic, socioeconomic and cultural factors in Ethiopia are highly favourable for the occurrence and spread of leptospirosis in horses and given the important role horses play in the economy of the country the current study was therefore 
carried out to determine serovar diversity, risk factors and prevalence of leptospirosis in the cart horse population of Central and Southern Ethiopia.

\section{Materials and methods}

\subsection{Study area}

The study was conducted on cart horses coming to the mobile and permanent clinics of a welfare organisation called the Society for the Protection of Animals Abroad (SPANA) Ethiopia project and government veterinary clinics of some nearby towns. SPANA Ethiopia is a joint collaboration project between the UK based animal welfare charity (SPANA UK) and the College of Veterinary Medicine and Agriculture of Addis Ababa University, SPANA Ethiopia. It works to alleviate the suffering of working animals by improving their health and welfare in the world's poorest countries of the world including Ethiopia. The study was conducted between December 2013 and February 2014 in 13 districts in Ethiopia namely; Adama, Akaki, Bishoftu, Hawassa, Modjo, Ziway (Batu), Dera, Meki, Sebeta, Welenchiti, Wenji, Metehara and Shashemene. The districts are located in 6 zones in the central and southern parts of the country, with various climates and agroecology (Table 1). These towns and their surroundings are working areas of the permanent and mobile clinics of SPANA Ethiopia project (Fig. 1). Ethiopia is a Federal Democratic Republic composed of 9 National Regional states: namely Tigray, Afar, Amhara, Oromia, Somali, Benishangul-Gumuz, Southern Nations Nationalities and People Region (SNNPR), Gambella And Harari and two Administrative states (Addis Ababa City administration and Dire Dawa city council). The national regional states as well as the two cities administrative councils are further divided into 800 woreda (districts). The study was conducted only in central and southern parts of Ethiopia in the States of Oromia, Addis Abba and SNNPR. Eleven out of the 13 study sites were in Oromia regional state. Oromia consists of a total of 180 districts. Akaki falls under 
Addis Ababa City Administration and Hawassa is in the SNNPR. Because of ease of accessibility the study focused on districts where SPANA Ethiopia is working or from nearby towns which have government clinics.

Table 1

Description of study sites/districts in Central and Southern Ethiopia

\begin{tabular}{|c|c|c|c|c|c|c|}
\hline Study area & $\begin{array}{l}\text { Regional } \\
\text { State }\end{array}$ & Zone & Agroecology & $\begin{array}{l}\text { Altitude } \\
\text { (masl) }\end{array}$ & $\begin{array}{l}\text { Average annual } \\
\text { rainfall (mm) }\end{array}$ & Temp $\left({ }^{0} \mathrm{C}\right)$ \\
\hline Shashemene & Oromia & $\begin{array}{l}\text { Western } \\
\text { Arsi }\end{array}$ & Highland & 2080 & 1750 & $15-23$ \\
\hline Bishoftu & Oromia & East Shoa & Midland & 1900 & 1151.6 & $8.5-30.7$ \\
\hline Adama & Oromia & East Shoa & Lowland & 1500 & $400-800$ & $13.9-27.7$ \\
\hline Modjo & Oromia & East Shoa & Lowland & 1500 & 500 & $11.3-35$ \\
\hline Wenji & Oromia & East Shoa & Lowland & 1510 & 850 & $17-30$ \\
\hline Ziway & Oromia & East Shoa & Lowland & 1649 & 650 & $12-27$ \\
\hline Dera & Oromia & East Shoa & Lowland & 1585 & 600 & $20-27$ \\
\hline Meki & Oromia & South Shoa & Lowland & 1636 & 750 & $22-28$ \\
\hline Sebeta & Oromia & West Shoa & Highland & 2356 & 1650 & 8-19 \\
\hline Welenchiti & Oromia & East Shoa & Lowland & 1400 & $550-700$ & $28-34$ \\
\hline Metehara & Oromia & East Shoa & Lowland & 947 & 507.3 & $25-40$ \\
\hline \multirow[t]{2}{*}{ Akaki } & Addis & Addis & Midland & 1900 & 1151.6 & $13.5-25.8$ \\
\hline & Ababa & Ababa & & & & \\
\hline Hawassa & SNNPR & Sidama & Midland & 1790 & 900 & $20.1-30$ \\
\hline
\end{tabular}

Source: CSA (2013); Tafese, Jibat, Aklilu, Zewdu, and Kumsa (2013); Dinka et al. (2007)

masl= metres above sea level 


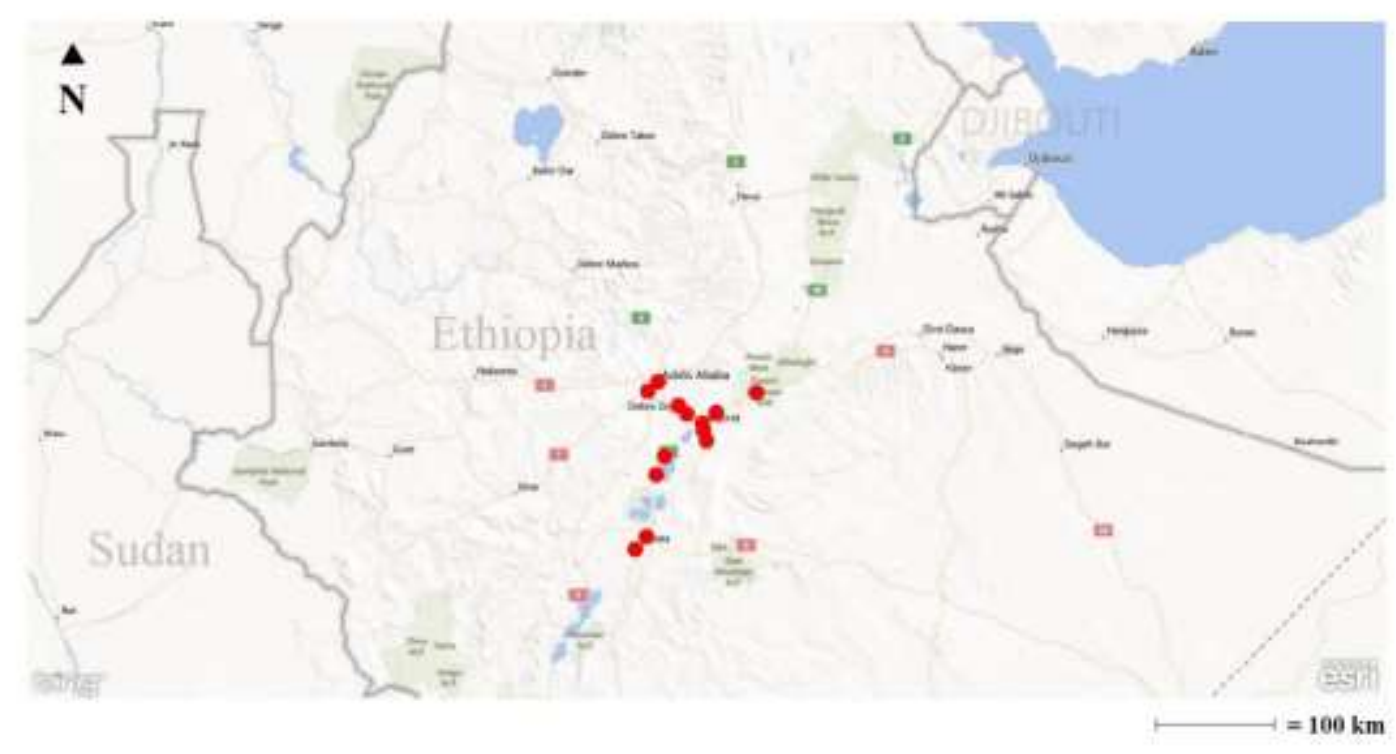

Fig. 1 Distribution of sampling districts in Central and Southern Ethiopia (Source: Epi Info ${ }^{\mathrm{TM}}$ )

The study areas are also known for their high equine population, poor welfare condition and low income status of horse owners. The farming system in all of the districts is characterized by a mixed crop-livestock production system. The livestock in the study areas are traditionally managed under extensive production systems.

\subsection{Serological survey design}

Ethical approval was obtained from James Cook University human research ethics committee (application no H5724). The study population comprised 5660 municipality registered cart horses in Central and Southern Ethiopia where the study was conducted (Tafese et al., 2013). Because, it was believed that some people may not have registered their horses, an assumption was made that $10 \%$ of the total cart horse owners failed to register their horses and hence the total population of cart horses in Central and South Eastern Ethiopia was estimated to be around 6226.

The sample size used for the project was calculated based on the assumption that at least $10 \%$ of the cart horses in Central and Southern Ethiopia were seropositive for each of the 24 
serovars of leptospirosis screened for in the study (Table 2). The total number of horses required to find one horse seropositive for Leptospira was calculated based on the formula to detect disease given by Thrusfield (2007) using a 95\% confidence level (Eq. 1).

$n=\left[1-\left(1-p_{1}\right)^{\frac{1}{D}}\right]\left[N-\frac{D-1}{2}\right] \quad$ Eq. 1

Where $\mathrm{n}$ is the required sample size

$p_{1}=$ confidence level

$\mathrm{D}=$ number of horses with a particular Leptospira serovar

$\mathrm{N}=$ population size

Each district was sampled separately and none of the districts had a population size of $<250$ horses. As a result, assuming a constant seroprevalence of leptospirosis of $10 \%$ within the population of each district, the minimum sample size required was 28 horses for each district to detect one horse with each of the 24 serovars, if present in the population. Thus an attempt was made to sample at least 28 cart horses from each district (Fig. 1). The total number of samples required for the 13 districts was 364 cart horses. However 418 cart horses from the 13 districts were bled for the study, providing some room for error. It must be noted that the study was designed to determine what serovars were within the equine population of each district and not the prevalence of leptospirosis at district level. However, a sample size of 28 horses would also allow an estimation of prevalence at an assumed prevalence rate of $2 \%$ and $5 \%$ margin of error (Eq. 2) (Thrusfield, 2007).

$\mathrm{n}=\frac{\mathrm{Z}_{\alpha / 2}^{2} * \mathrm{P}(1-\mathrm{P}) * \mathrm{D}}{\mathrm{E}^{2}}$ (Eq. 2)

$\mathbf{n}=$ sample size required 
$\mathbf{Z}_{\mathbf{a} / \mathbf{2}}=$ normal deviate for a two-tailed alternative hypothesis for a level of significance (for a $5 \%$ level of significance $\mathbf{Z}_{\boldsymbol{\alpha} / \mathbf{2}}$ is 1.96 ).

$\mathbf{P}=$ estimated prevalence of infection in the horse population.

$\mathbf{E}=$ precision or margin of error.

$\mathbf{D}=$ design effect ( 1 is used for simple random sampling).

Owners of horses were approached to participate in the questionnaire survey and have their horses bled as they presented themselves to the clinic for routine assistance. Bleeding of consenting owners horses continued at a clinic until a minimum of 28 horses were obtained for each district sampled. Owners were not aware of the survey prior to arriving at a clinic and self-selected themselves for presentation at a clinic. The majority of horses presenting at SPANA clinics were for welfare reasons.

\subsection{Questionnaire survey design}

A questionnaire survey was carried out on owners of the horses bled in the serological survey to obtain information on the horse's demographic profile (breed, sex and age), the geographical and environmental factors (district and the type of agricultural activities prevalent in the locality) and management factors (water sources, other species of animals present in the horse paddock and in the neighbourhood) that may be associated with leptospirosis. Owners were also asked if their cart horses had exhibited signs related to leptospirosis such as ocular disease, high fever, abortion and still births.

A database of leptospiral serovars was generated after serum samples from the cart horses were sent to the Bacterial Serology laboratory at the Agricultural Research CouncilOnderstepoort Veterinary Institute (ARC-OVI), in Pretoria, South Africa to be tested for the presence of antibodies to leptospiral serovars using the microscopic agglutination test (MAT). The ARC-OVI follow methods prescribed in the Manual of Diagnostic Tests and Vaccines for Terrestrial Animals, of the Office International des Epizooties (OIE), Paris, France, for 
leptospirosis (OIE, 2015). A panel of 24 live strains of Leptospira spp (representing 24 serovars and 19 serogroups) were used to screen the serum (Table 2). These reference strains were obtained from the Royal Tropical Institute in Amsterdam, The Netherlands. The serovars were thought to represent those circulating in Africa, including the ones commonly involved in human infections, as well as exotic serovars known to occur in other continents.

\subsection{Data Analysis}

Results were analyzed at James Cook University, Townsville, Australia who received the serological results from the ARC-OVI and the questionnaire results from SPANA Ethiopia. Serological results were adjusted for any cross-reactions among different serovars within the same serogroup before they were consolidated for further analysis. Data from the questionnaire forms completed at SPANA clinics were entered into the software package Epi Info 7 for analysis.

Apparent prevalence (AP) for Central and Southern Ethiopia was calculated based on proportion of cart horses positive to specific serovars. In addition, AP of leptospirosis was calculated for the three agroecological zones in which the 13 districts are located. It was assumed that agroecologies with one or more horses reacting positively to one or more of the 24 serovars of Leptospira at a serum dilution of 1:100 were considered seropositive. A serovar-specific AP for each of the 24 serovars along with their $95 \%$ confidence interval (CI) was calculated and the serodominant serovar was determined (Table 2).

The proportion of Leptospira seropositive horses in different categories and groups was calculated. Similarly, the proportion of seropositive horses to the predominant serovar (Bratislava) in different categories and groups was also calculated. A univariate analysis for the association between Leptospira seropositive cart horses and various risk factors shown in Table 4, 5 and 7 was carried out using the Chi-square test. Risk factors showing a significant 
association on the univariate analysis $(\mathrm{P}<0.15)$ were included in a multivariable logistic regression model (Katz, 1999). Two models were developed; the first looking at Leptospira seropositive horses irrespective of serovar and the second looking specifically at serovar Bratislava (the most prevalent serovar) positive horses. Regression models for the other serovars were not reliable due to the small number of positive horses for these serovars.

For the logistic regression models a hierarchical forward switching algorithm was used to examine for interactions and determine the best model fit. With this algorithm, the term with the largest log likelihood is entered into the regression model. The term which increases the $\log$ likelihood the most when combined with the first term is entered next. Then, each term in the current model is removed and the rest of the terms are checked to determine if, when they are used instead, the likelihood function is increased. If a term can be found by this switching process, the switch is made and the whole switching operation is begun again. The algorithm continues until no term can be found that improves the likelihood. This model then becomes the best two-term model. Next, the subset size is increased by one, the best third term is entered into the model, and the switching process is repeated. This process is repeated until the maximum subset size is reached. Hence, this model finds the optimum subset for each subset size. One run is made to find an appropriate subset size by looking at the change in the $\log$ likelihood, then the maximum subset size is reset to this value and the model rerun. With hierarchical models only those terms that will keep the model hierarchical are candidates for addition or deletion.

The final logistic regression models after hierarchical forward selection were then further reduced by backward elimination, removing each independent variable with Wald-P $>0.05$ until all the remaining variables were significant (Wald-P $<0.05$ ). Since the algorithms used did not account for possible confounding, the backward elimination process helped counter any confounding that may have been present in the model and also served to verify that the 
final model was valid (Dahoo et al., 2009). A value of Wald-P $<0.05$ was considered statistically significant. Statistical analysis was carried out using the software packages NCSS 9 (Hintze, 2013) and Epi Info 7.

\section{Results}

\subsection{Prevalence of Leptospirosis in the Cart Horse Population of Central and Southern} Ethiopia

A total of 184 out of 418 horses had antibody titres of 1:100 or greater to at least one of 16 serovars demonstrating the presence of 16 serovars of Leptospira species in Central and Southern Ethiopian horses. This means, 44\% (95\% CI: 39, 48.7) of the sampled horses were seropositive to at least one serovar. Titres to serovar Bratislava were the most common (34.45 $\%)$ and they ranged from 1:100 to 1:3200; followed by seovars Djasiman (9.8\%), Topaz $(6.0 \%)$ and Pomona (5.3\%). The panel of antigens used for the MAT contained 24 serovars representing 19 serogroups, of which 16 serovars from 14 serogroups were detected (Table 2).

Of the 418 cart horses tested, 119 horses had titres to a single serovar and 65 horses had titres to two or more serovars. The apparent prevalence of each serovar within the horses sampled is shown in Table 2. The highest antibody titre was recorded for serovars Pomona and Bratislava (maximum dilution $=1: 3200$ ). For Bratislava the modal titre was 100 with 144 samples testing positive at a titre of 100 or greater. For Bratislava $73 \%$ of titres were 100 -200 and only $2 \%$ of titres were $1600-3200$ while for Pomona $52 \%$ of titres were $100-200$ and $29 \%$ were $1600-3200$. For the remaining serovars $98 \%$ had titres of $100-200$. 
Table 2

The apparent prevalence of 24 serovars of Leptospira in cart horses in Central and Southern Ethiopia

\begin{tabular}{|c|c|c|c|}
\hline Serovar & Serogroup & $\begin{array}{c}\text { No. of seropositive } \\
\text { horses }(n=418)\end{array}$ & $\begin{array}{c}\text { Apparent Prevalence } \\
\text { (\%) with }[95 \% \mathrm{CI}]\end{array}$ \\
\hline Bratislava & Australis & 144 & $34.5[29.9,39.3]$ \\
\hline Djasiman & Djasiman & 41 & $9.8[7.2,13.2]$ \\
\hline Topaz & Tarassovi & 25 & $6.0[4.0,8.8]$ \\
\hline Pomona & Pomona & 22 & $5.3[3.4,8.0]$ \\
\hline Medanensis & Sejroe & 10 & $2.4[1.2,4.5]$ \\
\hline Grippotyphosa & Grippotyphosa & 7 & $1.7[0.7,3.6]$ \\
\hline Arboreae & Ballum & 6 & $1.4[0.9,3.3]$ \\
\hline Bulgarica & Autumnalis & 5 & $1.2[0.4,2.9]$ \\
\hline Kremastos & Hebdomadis & 5 & $1.2[0.4,2.9]$ \\
\hline Canicola & Canicola & 4 & $1.0[0.3,2.6]$ \\
\hline Cynopteri & Cynopteri & 3 & $0.7[0.2,2.6]$ \\
\hline Javanica & Javanica & 3 & $0.7[0.2,2.3]$ \\
\hline Bataviae & Bataviae & 2 & $0.5[0.1,1.9]$ \\
\hline Zanoni & Pyrogenes & 2 & $0.5[0.1,1.9]$ \\
\hline Hebdomadis & Hebdomadis & 1 & $0.2[0.0,1.5]$ \\
\hline Hardjo type Prajitno & Sejroe & 1 & $0.2[0.0,1.5]$ \\
\hline Australis & Australis & 0 & - \\
\hline Celledoni & Celledoni & 0 & - \\
\hline Icterohaemorrhagiae & Icterohaemorrhagiae & 0 & - \\
\hline Szwajizak & Mini & 0 & - \\
\hline Panama & Panama & 0 & - \\
\hline Robinsoni & Pyrogenes & 0 & - \\
\hline Shermani & Shermani & 0 & - \\
\hline Tarassovi & Tarassovi & 0 & - \\
\hline
\end{tabular}

3.2. Leptospiral Seroprevalence in the Three Agroecologies of Central and Southern Ethiopia

The highest percentage of seropositivity $(62.1 \%)$ was noted in horses from the highland agroecology followed by midland (44.4\%). A relatively lower percentage of seropositivity (39.9\%) was recorded in horses from the lowland agroecology. The seroprevalence of 
leptospirosis was significantly higher $(\mathrm{P}<0.01)$ in horses from both highland and midland than in horses from the lowland agroecology (Table 3).

\section{Table 3}

Apparent prevalence (AP) of 24 serovars of Leptospira in cart horses in the three agro-ecological zones of Central and Southern Ethiopia

\begin{tabular}{|c|c|c|c|c|c|c|}
\hline \multirow[b]{2}{*}{ Serovar } & \multicolumn{2}{|c|}{ Lowland } & \multicolumn{2}{|r|}{ Midland } & \multicolumn{2}{|c|}{ Highland } \\
\hline & $\begin{array}{c}\text { No } \\
(\mathrm{n}=261)\end{array}$ & $\begin{array}{c}\text { AP (\%) with } \\
{[95 \% \text { CI }]}\end{array}$ & $\begin{array}{c}\text { No } \\
(\mathrm{n}=91)\end{array}$ & $\begin{array}{c}\text { AP (\%) with } \\
{[95 \% \mathrm{CI}]}\end{array}$ & $\begin{array}{c}\text { No } \\
(n=58)\end{array}$ & $\begin{array}{c}\text { AP (\%) with } \\
{[95 \% \mathrm{CI}]}\end{array}$ \\
\hline Bratislava & 84 & $32.2[26.6,38.2]$ & 34 & $34.3[25.1,44.6]$ & 26 & $44.8[31.7,58.5]$ \\
\hline Djasiman & 23 & $8.8[5.7,12.9]$ & 10 & $10.1[5.0,17.8]$ & 8 & $13.8[6.2,25.4]$ \\
\hline Pomona & 15 & $5.7[3.3,9.3]$ & 5 & $5.1[1.7,11.4]$ & 2 & $3.5[0.4,11.9]$ \\
\hline Topaz & 12 & $4.6[2.4,7.9]$ & 7 & $7.1[2.9,14.0]$ & 6 & $10.3[3.9,21.2]$ \\
\hline Medanensis & 8 & $3.1[1.3,6.0]$ & 2 & $2.0[0.3,7.1]$ & 0 & $0[0,6.2]$ \\
\hline Grippotyphosa & 4 & $1.5[0.4,3.9]$ & 3 & $3.0[0.6,8.6]$ & 0 & $0[0,6.2]$ \\
\hline Arboreae & 2 & $0.8[0.1,2.7]$ & 2 & $2.0[0.3,7.1]$ & 2 & $3.5[0.4,11.9]$ \\
\hline Bulgarica & 2 & $0.8[0.1,2.7]$ & 1 & $1.0[0.0,5.5]$ & 2 & $3.5[0.4,11.9]$ \\
\hline Bataviae & 1 & $0.4[0.0,2.1]$ & 1 & $1.0[0.0,5.5]$ & 0 & $0[0,6.2]$ \\
\hline Cynopteri & 1 & $0.4[0.0,2.1]$ & 2 & $2.0[0.3,7.1]$ & 0 & $0[0,6.2]$ \\
\hline Kremastos & 1 & $0.4[0.0,2.1]$ & 0 & $0[0,3.7]$ & 4 & $6.9[1.9,16.7]$ \\
\hline Canicola & 0 & $0[0,1.4]$ & 2 & $2.0[0.3,7.1]$ & 2 & $3.5[0.4,11.9]$ \\
\hline Hardjo & 0 & $0[0,1.4]$ & 0 & $0[0,3.7]$ & 1 & $1.72[0.0,9.2]$ \\
\hline Hebdomadis & 0 & $0[0,1.4]$ & 0 & $0[0,3.7]$ & 1 & $1.72[0.0,9.3]$ \\
\hline Javanica & 0 & $0[0,1.4]$ & 3 & $3.0[0.6,8.6]$ & 0 & $0[0,6.2]$ \\
\hline Zanoni & 0 & $0[0,1.4]$ & 0 & $0[0,3.7]$ & 2 & $3.5[0.4,11.9]$ \\
\hline Australis & - & - & - & - & - & - \\
\hline Celledoni & - & - & - & - & - & - \\
\hline Icterohaemorrhagiae & - & - & - & - & - & - \\
\hline Panama & - & - & - & - & - & - \\
\hline Robinsoni & - & - & - & - & - & - \\
\hline Shermani & - & - & - & - & - & - \\
\hline Szwajizak & - & - & - & - & - & - \\
\hline Tarassovi & - & - & - & - & - & - \\
\hline
\end{tabular}

Apparent prevalence of all serovars was calculated (Table 3) where serovar Bratislava was the predominant serovar in all agroecologies followed by serovars Djasiman and Pomona. Seroprevalence to serovars Bratilslava, Djasiman and Topaz increased with the increase in 
altitude. Horses from the highland had higher seroprevalence to these serovars followed by horses from the midland and lowland respectively. Contrary to this trend, serovar Pomona showed no significant difference in prevalence between the lowlands and midlands.

\subsection{Risk Factors for Associations with Leptospira}

Ethiopian horses have not been systematically characterized and documented in terms of their observed phenotypic characteristics (Kefena et al., 2012), which made it difficult to group them based on breed. Therefore, an attempt was made to categorize them as local, exotic and cross breeds. However, all of the horses sampled were local breed and male and were used as cart drawing draft animals. In Ethiopia almost all carthorses (>99\%) are male horses comprising stallions and geldings. The female horses are kept for breeding in the highlands where they are sometimes used as riding (saddle) horses but not as cart horses. Breeding horses in urban towns is difficult due to limited space and owners are usually not economically capable of keeping pregnant mares. Thus the association of breed, gender and use of cart horses was not analysed.

\subsubsection{Risk associated with Leptospira seropositivity irrespective of serovar}

The results of the Univariate analysis for associations between risk factors grouped by geographic and environmental factors and by management factors are shown in Tables 4 and 5 respectively. Associations found to be significant in the univariate analyses $(\mathrm{P}<0.15)$ were assessed by multivariable logistic regression to control for confounding factors. Age of the sampled cart horses ranged from 3 to 18 years with a median age of 10 years. Horses were classified into three age groups (0-6, 7-12 and 13 and above). There were no significant associations between horses showing clinical signs (ocular disease, high fever and yellow decolourisation of mucous membranes) in the last 12 months and seropositive horses. Age, agroecology, horse origin/district, presence of rodents, dogs in the vicinity, the use of river 
water for drinking, fodder and papaya plantation in the vicinity were significantly associated with seropositivity to Leptospira in the Univariate analysis and included in the multivariable logistic regression models.

\section{Table 4}

Univariate results and apparent prevalence (AP) of cart horses seropositive to Leptospira by geographic and environmental factors

\begin{tabular}{|c|c|c|c|c|c|}
\hline Variable & $\begin{array}{c}\text { No of tested } \\
\text { horses }\end{array}$ & $\begin{array}{c}\text { No of positive } \\
\text { horses (AP \%) }\end{array}$ & $\begin{array}{c}\text { 95\% CI for } \\
\text { AP }\end{array}$ & Pearson's $\chi^{2}$ & P-Value \\
\hline Agroecology & & & & 9.5 & $<0.01$ \\
\hline Highland & 58 & $36(62.1)$ & $49.6-74.6$ & & \\
\hline Midland & 99 & $44(44.4)$ & $34.6-54.2$ & & \\
\hline Lowland & 261 & 104 (39.9) & $33.9-45.8$ & & \\
\hline District & & & & 30.5 & $<0.01$ \\
\hline Adama & 42 & $20(47.6)$ & $32.5-62.7$ & & \\
\hline Akaki & 30 & $12(4)$ & $22.5-57.5$ & & \\
\hline Wonji & 28 & $7(25)$ & $9.0-41.0$ & & \\
\hline Meki & 34 & $9(26.5)$ & $11.6-41.3$ & & \\
\hline Ziway & 29 & $20(69)$ & $52.1-85.8$ & & \\
\hline Dera & 28 & $10(35.7)$ & $18.0-53.5$ & & \\
\hline Mojo & 33 & $16(48.5)$ & $31.4-65.5$ & & \\
\hline Sebeta & 29 & $17(58.6)$ & $40.7-76.5$ & & \\
\hline Welenchiti & 38 & $10(26.3)$ & $12.3-40.3$ & & \\
\hline Bishoftu & 39 & $17(43.6)$ & $28.0-59.2$ & & \\
\hline Shashemene & 29 & $19(65.5)$ & $48.2-82.8$ & & \\
\hline Hawassa & 30 & $15(50)$ & $32.1-67.9$ & & \\
\hline Metehara & 29 & $12(41.4)$ & $23.5-59.3$ & & \\
\hline \multicolumn{6}{|c|}{ Sugarcane fields in the locality } \\
\hline Yes & 74 & $31(41.9)$ & $30.7-53.1$ & 0.2 & 0.68 \\
\hline No & 344 & $153(44.5)$ & $39.2-49.7$ & & \\
\hline \multicolumn{6}{|c|}{ Banana fields in the locality } \\
\hline Yes & 22 & $7(31.8)$ & $12.4-51.3$ & 1.4 & 0.24 \\
\hline No & 396 & $177(44.7)$ & $39.8-49.6$ & & \\
\hline \multicolumn{6}{|c|}{ Papaya fields in the locality } \\
\hline Yes & 41 & $12(29.3)$ & $15.3-43.2$ & 4.0 & 0.05 \\
\hline No & 377 & $172(45.6)$ & $40.6-50.7$ & & \\
\hline \multicolumn{6}{|c|}{ Fodder plantation in the locality } \\
\hline Yes & 21 & $14(66.7)$ & $46.5-86.8$ & 4.6 & 0.03 \\
\hline No & 397 & $170(42.8)$ & $38.0-47.7$ & & \\
\hline
\end{tabular}




\section{Table 5}

Univariate results and apparent prevalence (AP) of cart horses seropositive to Leptospira by management factors

\begin{tabular}{|c|c|c|c|c|c|}
\hline Variable & $\begin{array}{l}\text { No of tested } \\
\text { horses }\end{array}$ & $\begin{array}{l}\text { No of positive } \\
\text { horses }(\text { AP \%) }\end{array}$ & $95 \%$ CI for AP & Pearson's $\chi^{2}$ & P-Value \\
\hline & \multicolumn{5}{|l|}{ Water source } \\
\hline & \multicolumn{5}{|l|}{ Municipal water } \\
\hline Yes & 353 & $156(44.2)$ & $39.0-49.4$ & 0.0 & 0.87 \\
\hline \multirow[t]{2}{*}{ No } & 65 & $28(43.08)$ & $31.0-55.1$ & & \\
\hline & \multicolumn{5}{|l|}{ River } \\
\hline Yes & 142 & $72(50.7)$ & $42.5-58.9$ & 3.9 & 0.05 \\
\hline \multirow[t]{2}{*}{ No } & 276 & $112(40.6)$ & $34.8-46.4$ & & \\
\hline & \multicolumn{5}{|c|}{ Pond/stagnant pool } \\
\hline Yes & 48 & $17(35.4)$ & $21.9-48.9$ & 1.63 & 0.20 \\
\hline \multirow[t]{2}{*}{ No } & 370 & $167(45.1)$ & $40.1-50.2$ & & \\
\hline & \multicolumn{5}{|c|}{$\begin{array}{l}\text { Domesticated animal species in neighbouring properties } \\
\text { Cattle }\end{array}$} \\
\hline Yes & 99 & $47(47.5)$ & $37.6-57.3$ & 0.6 & 0.43 \\
\hline No & 319 & $137(43.0)$ & $37.5-48.4$ & & \\
\hline \multicolumn{6}{|l|}{ Dog } \\
\hline Yes & 395 & $169(42.8)$ & $37.9-47.7$ & 4.4 & 0.04 \\
\hline No & 23 & $15(65.2)$ & $45.8-84.7$ & & \\
\hline \multicolumn{6}{|l|}{ Pig } \\
\hline Yes & 42 & $19(45.2)$ & $30.2-60.3$ & 0.0 & 0.87 \\
\hline No & 376 & 165 (43.9) & $38.9-48.9$ & & \\
\hline \multicolumn{6}{|l|}{ Sheep } \\
\hline Yes & 95 & $43(45.3)$ & $35.3-55.3$ & 0.1 & 0.78 \\
\hline No & 323 & $141(43.7)$ & $38.2-49.1$ & & \\
\hline \multicolumn{6}{|l|}{ Cat } \\
\hline Yes & 247 & $110(44.5)$ & $38.3-50.7$ & 0.1 & 0.80 \\
\hline No & 171 & $74(43.3)$ & $35.8-50.7$ & & \\
\hline \multicolumn{6}{|c|}{ Presence of rodents in the property } \\
\hline Yes & 297 & $140(47.1)$ & $41.5-52.8$ & 4.1 & 0.04 \\
\hline No & 121 & $44(36.4)$ & $27.8-44.9$ & & \\
\hline \multicolumn{6}{|l|}{ Age } \\
\hline$\leq 6$ Years old & 32 & $8(25)$ & $10.0-40.0$ & 17.2 & $<0.01$ \\
\hline 7-12 Years old & 275 & $110(40)$ & $34.2-45.8$ & & \\
\hline$\geq 13$ Years old & 111 & $66(59.5)$ & $50.3-68.6$ & & \\
\hline
\end{tabular}

Multivariable logistic regression found risk factors that were significantly associated with seropositive horses for Leptospira were age (with the greatest risk being in the 7-12 year old group $(\mathrm{OR}=5))$, the use of river water for drinking, papaya plantations in the vicinity and particular districts as shown in Table 6. Collinearity between districts and agroecological zones resulted in agroecological zones being dropped from the model in favour of districts.

The final model for Leptospira seropositive $=-0.26+0.90 *($ age $=7-12)+1.60 *($ age $>=13)-$ 
$0.48 *($ district $=1)-1.53 *($ district $=2)-2.49 *($ district $=3)-1.51 *($ district=4 $)-0.13 *($ district $=5)-$

$1.82 *($ district=6) $-0.60 *($ district $=7)-0.58 *($ district $=8)-1.40 *($ district $=9)-0.97 *($ district $=10)-$ $0.54 *($ district $=12)-1.76 *($ district $=13)+1.03 *($ river=1 $)-0.90 *($ papaya $=1)$. The percent correctly classified by the model was $65.6 \%$. The names of districts are shown in Table 6 and presented in the same order.

\section{Table 6}

Multivariable logistic regression analysis results in the overall model for leptospiral seropositivity using data from 418 cart horses

\begin{tabular}{|c|c|c|c|c|c|}
\hline \multirow[t]{2}{*}{ Variable } & \multirow[t]{2}{*}{ Category } & \multicolumn{4}{|c|}{ Overall seropositivity } \\
\hline & & OR $[95 \% \mathrm{CI}]$ & Coefficient & Std. error & $\mathrm{P}$ - value \\
\hline & Intercept & 0.8 & -0.26 & - & - \\
\hline \multirow[t]{3}{*}{ Age } & $\leq 6$ & 1 & - & - & - \\
\hline & $7-12$ & $5.0[1.9,12.7]$ & 1.60 & 0.48 & $<0.01$ \\
\hline & $\geq 13$ & $2.5[1,6.0]$ & 0.90 & 0.50 & 0.05 \\
\hline \multirow[t]{2}{*}{ River } & No & 1 & - & - & - \\
\hline & Yes & $2.8[1.5,5.3]$ & 1.03 & 0.32 & $<0.01$ \\
\hline \multirow[t]{2}{*}{ Papaya } & No & 1 & - & - & - \\
\hline & Yes & $0.41[0.2,1.0]$ & -0.90 & 0.41 & 0.03 \\
\hline \multirow[t]{13}{*}{ District } & Shashemene & 1 & - & - & - \\
\hline & Wonji & $0.1[0.0,0.3]$ & -2.49 & 0.66 & $<0.01$ \\
\hline & Dera & $0.16[0.0,0.6]$ & -1.83 & 0.64 & $<0.01$ \\
\hline & Akaki & $0.2[0.1,0.9]$ & -1.53 & 0.58 & $<0.01$ \\
\hline & Metehara & $0.2[0.1,0.6]$ & -1.76 & 0.61 & $<0.01$ \\
\hline & Meki & $0.2[0.1,0.7]$ & -1.51 & 0.59 & 0.01 \\
\hline & Welenchiti & $0.3[0.1,0.7]$ & -1.40 & 0.57 & 0.01 \\
\hline & Bishoftu & $0.4[0.1,1.0]$ & -0.10 & 0.54 & 0.07 \\
\hline & Mojo & $0.6[0.2,1.7]$ & -0.60 & 0.56 & 0.29 \\
\hline & Adama & $0.6[0.2,1.8]$ & -0.48 & 0.53 & 0.36 \\
\hline & Ziway & $0.9[0.3,2.8]$ & -0.13 & 0.60 & 0.83 \\
\hline & Sebeta & $0.6[0.2,1.7]$ & -0.58 & 0.58 & 0.32 \\
\hline & Awassa & $0.6[0.2,1.8]$ & -0.54 & 0.57 & 0.34 \\
\hline
\end{tabular}




\subsubsection{Risk associated with serovar Bratislava}

Age, horse origin/district, banana fields in the vicinity, fodder plantation in the vicinity, use of river as source of water, and the presence of dogs and sheep in the neighbourhood were found to be significant on the Univariate analysis (Table 7) and were further modelled using multivariable logistic regression (Table 8) to determine the set of risk factors that best predicts the outcome of being seropositive to serovar Bratislava. In the process, the variables fodder plantation, banana fields, and sheep in the neighbourhood were removed because of their insignificance and the final model was left with the remaining four variables.

Horses $>13$ years of age were more likely to be seropositive to serovar Bratislava than younger horses $(\mathrm{OR}=3.46)$ (Table 8). Also, cart horses from Ziway (Batu), Shashemene and Sebeta had significant associations with serovar Bratislava seropositive horses as compared to the other districts (Table 7) and the use of river water for drinking increased the risk of seropositivity to serovar Bratislava $(\mathrm{OR}=2.5)$,

The presence of dogs in the vicinity decreased the risk of being seropositive to serovar Bratislava by nearly a third $(\mathrm{OR}=0.33)$.

The final model for seropositivity to Leptospira serovar Bratislava $=0.72+0.39 *$ (Age $=7$ $12)+1.24 *($ Age $>=13)-0.49 *($ district $=1)-0.98 *($ district $=2)-1.76 *($ district $=3)-$ $0.89 *($ district $=4)+0.51 *($ district $=5)-1.25 *($ district $=6)-0.52 *($ district $=7)-0.29 *($ district $=8)-$ $0.85 *($ district $=9)-0.57 *($ district $=10)-0.20 *($ district $=12)-0.96 *($ district $=13)+0.93 *($ river $=1)$ $-1.11 *(\operatorname{dog}=1)$. The percent correctly classified by the model was $64.6 \%$. The names of districts are shown in Table 8 and presented in the same order. 


\section{Table 7}

Univariate results and apparent prevalence (AP) of seropositive cart horses for serovar Bratislava by age, agroeclogy, district and management factors

\begin{tabular}{|c|c|c|c|c|c|}
\hline Variable & No of tested horses & $\begin{array}{c}\text { No of positive horses } \\
\text { (AP \%) }\end{array}$ & $\begin{array}{c}95 \% \text { CI for } \\
\text { AP }\end{array}$ & Pearson's $\chi^{2}$ & P-Value \\
\hline & \multicolumn{5}{|c|}{ Age } \\
\hline$\leq 6$ Years old & 32 & $7(21.9)$ & $7.6-36.2$ & 16.0 & $<0.01$ \\
\hline 7-12 Years old & 275 & $82(29.8)$ & $24.4-35.2$ & & \\
\hline \multirow{2}{*}{$\geq 13$ Years old } & 111 & $55(49.6)$ & $40.2-58.9$ & & \\
\hline & \multicolumn{5}{|l|}{ Agroecology } \\
\hline Highland & 58 & $26(44.8)$ & $32.0-57.6$ & 3.3 & 0.19 \\
\hline Midland & 99 & $34(34.3)$ & $25.0-43.7$ & & \\
\hline \multirow[t]{2}{*}{ Lowland } & 261 & $84(32.1)$ & $26.5-37.9$ & & \\
\hline & \multicolumn{5}{|l|}{ District } \\
\hline Adama & 42 & $13(31.0)$ & $17.0-44.9$ & 24.0 & 0.02 \\
\hline Akaki & 30 & $10(33.3)$ & $16.5-50.2$ & & \\
\hline Wonji & 28 & $6(21.4)$ & $6.2-36.6$ & & \\
\hline Meki & 34 & $7(20.6)$ & $7.0-34.2$ & & \\
\hline Ziway & 29 & $19(65.5)$ & $48.2-82.8$ & & \\
\hline Dera & 28 & $9(32.1)$ & $14.8-49.4$ & & \\
\hline Mojo & 33 & $11(33.3)$ & $17.2-49.4$ & & \\
\hline Sebeta & 29 & $12(41.4)$ & $23.5-59.3$ & & \\
\hline Welenchiti & 38 & $8(21.1)$ & $8.1-34.0$ & & \\
\hline Bishoftu & 39 & $13(33.3)$ & $18.5-48.1$ & & \\
\hline Shashemene & 29 & $14(48.3)$ & $30.1-66.5$ & & \\
\hline Hawassa & 30 & $11(36.7)$ & $19.4-53.9$ & & \\
\hline \multirow[t]{2}{*}{ Metehara } & 29 & $11(37.9)$ & $20.3-55.6$ & & \\
\hline & \multicolumn{5}{|c|}{ Sugarcane fields in the locality } \\
\hline Yes & 74 & $26(35.1)$ & $24.3-46.0$ & 0.0 & 0.89 \\
\hline \multirow[t]{2}{*}{ No } & 344 & $118(34.3)$ & $29.3-39.3$ & & \\
\hline & \multicolumn{5}{|c|}{ Banana fields in the locality } \\
\hline Yes & 22 & $4(18.2)$ & $2.1-34.3$ & 2.7 & 0.01 \\
\hline \multirow[t]{2}{*}{ No } & 396 & $140(35.4)$ & $30.6-40.1$ & & \\
\hline & \multicolumn{5}{|c|}{ Papaya fields in the locality } \\
\hline Yes & 41 & $11(26.8)$ & $13.3-40.4$ & 1.2 & 0.28 \\
\hline \multirow[t]{2}{*}{ No } & 377 & $133(35.3)$ & $30.5-40.1$ & & \\
\hline & \multicolumn{5}{|c|}{ Fodder plantation in the locality } \\
\hline Yes & 21 & $12(57.1)$ & $36.0-78.3$ & 5.0 & 0.02 \\
\hline \multirow[t]{3}{*}{ No } & 397 & $132(33.3)$ & 28.6-37.9 & & \\
\hline & \multirow{2}{*}{\multicolumn{5}{|c|}{$\begin{array}{l}\text { Water source } \\
\text { Municipal water }\end{array}$}} \\
\hline & & & & & \\
\hline Yes & 353 & $121(34.3)$ & $29.3-39.2$ & 0.8 & 0.03 \\
\hline \multirow[t]{2}{*}{ No } & 65 & $23(35.4)$ & $23.8-47.0$ & & \\
\hline & \multicolumn{5}{|l|}{ River } \\
\hline Yes & 142 & $62(43.7)$ & $35.5-51.8$ & 8.1 & $<0.01$ \\
\hline \multirow{2}{*}{ No } & 276 & $82(29.7)$ & $24.3-35.1$ & & \\
\hline & \multicolumn{5}{|l|}{ Pond/stagnant pool } \\
\hline
\end{tabular}




\begin{tabular}{|c|c|c|c|c|c|}
\hline Yes & 48 & $15(31.3)$ & $18.1-44.4$ & 0.3 & 0.62 \\
\hline \multirow[t]{2}{*}{ No } & 370 & $129(34.9)$ & $30.0-39.7$ & & \\
\hline & \multicolumn{5}{|c|}{$\begin{array}{l}\text { Domesticated animal species in neighbouring properties } \\
\text { Cattle }\end{array}$} \\
\hline Yes & 339 & $120(35.4)$ & $30.3-40.5$ & 0.7 & 0.40 \\
\hline \multirow[t]{2}{*}{ No } & 79 & $24(30.4)$ & $20.2-40.5$ & & \\
\hline & Dog & & & & \\
\hline Yes & 395 & $130(32.9)$ & $28.3-37.5$ & 7.5 & $<0.01$ \\
\hline \multirow[t]{2}{*}{ No } & 23 & $14(60.9)$ & $40.9-80.8$ & & \\
\hline & Pig & & & & \\
\hline Yes & 42 & $16(38.1)$ & $23.4-52.8$ & 0.3 & 0.60 \\
\hline \multirow[t]{2}{*}{ No } & 376 & $128(34.0)$ & $29.3-38.8$ & & \\
\hline & Sheep & & & & \\
\hline Yes & 310 & $114(36.8)$ & $31.4-42.1$ & 2.9 & 0.09 \\
\hline \multirow[t]{2}{*}{ No } & 108 & $30(27.8)$ & $19.3-36.2$ & & \\
\hline & Cat & & & & \\
\hline Yes & 247 & $82(33.2)$ & 27.3-39.1 & 0.4 & 0.52 \\
\hline \multirow[t]{2}{*}{ No } & 171 & $62(36.3)$ & $29.1-43.5$ & & \\
\hline & Donkey & & & & \\
\hline Yes & 197 & $69(35.0)$ & $28.4-41.7$ & 0.1 & 0.82 \\
\hline \multirow[t]{2}{*}{ No } & 221 & 75 (33.9) & $27.7-40.2$ & & \\
\hline & Presence of rode & & & & \\
\hline Yes & 297 & $107(36.0)$ & $30.6-41.5$ & 1.1 & 0.29 \\
\hline No & 121 & $37(30.6)$ & $22.4-38.8$ & & \\
\hline
\end{tabular}




\section{Table 8}

Multivariable logistic regression analysis results for serovar Bratislava using data from 418 cart horses

\begin{tabular}{|c|c|c|c|c|c|}
\hline \multirow[t]{2}{*}{ Variable } & \multirow[t]{2}{*}{ Category } & \multicolumn{4}{|c|}{ Serovar Bratislava } \\
\hline & & OR $[95 \% \mathrm{CI}]$ & Coefficient & Std. error & $P$ - value \\
\hline & Intercept & 2.1 & 0.72 & - & - \\
\hline \multirow[t]{3}{*}{ Age } & $\leq 6$ & 1 & & - & - \\
\hline & $7-12$ & $1.5[0.6,3.8]$ & 0.39 & 0.48 & 0.41 \\
\hline & $\geq 13$ & $3.5[1.3,9.3]$ & 1.24 & 0.50 & 0.01 \\
\hline \multirow[t]{2}{*}{ River } & No & 1 & - & - & - \\
\hline & Yes & $2.5[1.3,4.6]$ & 0.91 & 0.32 & $<0.01$ \\
\hline \multirow[t]{2}{*}{ Dog } & No & 1 & - & - & - \\
\hline & Yes & $0.3[0.1,0.8]$ & -1.11 & 0.48 & 0.02 \\
\hline \multirow[t]{13}{*}{ District } & Shashemene & 1 & - & - & - \\
\hline & Wonji & $0.2[0.1,0.6]$ & -1.76 & 0.65 & $<0.01$ \\
\hline & Dera & $0.29[0.09,0.94]$ & -1.25 & 0.61 & 0.04 \\
\hline & Akaki & $0.378[0.12,1.15]$ & -0.98 & 0.57 & 0.09 \\
\hline & Metehara & $0.38[0.12,1.20]$ & -0.96 & 0.58 & 0.10 \\
\hline & Meki & $0.41[0.13,1.33]$ & -0.89 & 0.60 & 0.14 \\
\hline & Welenchiti & $0.43[0.14,1.33]$ & -0.85 & 0.58 & 0.14 \\
\hline & Bishoftu & $0.57[0.20,1.60]$ & -0.57 & 0.53 & 0.29 \\
\hline & Mojo & $0.59[.20,1.79]$ & -0.52 & 0.56 & 0.35 \\
\hline & Adama & $0.61[0.22,1.73]$ & -0.49 & 0.53 & 0.36 \\
\hline & Ziway & $1.67[0.54,5.12]$ & 0.51 & 0.57 & 0.37 \\
\hline & Sebeta & $0.75[0.25,2.21]$ & -0.29 & 0.55 & 0.60 \\
\hline & Awassa & $0.82[0.27,2.46]$ & -0.20 & 0.56 & 0.72 \\
\hline
\end{tabular}

\section{Discussion}

\subsection{Serovars Detected}

The present study was designed to detect which Leptospira serovars are present in Ethiopian cart horses of Central and Southern Ethiopia and identified 16 serovars representing 14 serogroups of Leptospira. A number of the serovars had never been described in Ethiopian horses before and this is the first report of Ethiopian horses having been exposed 
to these serovars; these being Bratislava, Djasiman, Topaz, Pomona, Medanensis, Arboreae, Bulgarica, Kremastos, Canicola, Cynopteri, Javanica, Bataviae, Zanoni, Hebdomadis and Hardjo (Pappas et al., 2008).

The high seroprevalence of Bratislava $(34.5 \%)$ in this study was in agreement with other studies that have also recorded higher seoprevalence for serovar Bratislava than for other serovars (Barwick et al., 1998; Pinna et al., 2007; Båverud et al., 2009). Some authors suggest, therefore, that the horse may be a maintenance host for this serovar (van den Ingh et al., 1989; Barwick et al., 1998) and the finding of this study contributes to the growing body of evidence that serovar Bratislava may be adapted to horses. This is supported by the lower titres $(100-200)$ found in the majority of horses.

Although serovar Butembo was reported as the predominant serovar in a previous survey in Ethiopia (Moch et al., 1975), it should be noted that serovar Bratislava was not included in the panel of antigens used for that study and the current study did not include serovars Butembo and Copenhageni in the panel of antigens used to screen the sera. Serovar Butembo falls in the Autumnalis serogroup which includes Bulgarica which we tested for and serovar Copenhageni falls in the Icterohaemorrhagiae serogroup which we tested for. In addition, we were interested in finding serovars that had not previously been reported in Ethiopian horses and because the work was paralleling that of work being done in Northern Australia and South Africa we included the same serovars being tested in those projects (Wangdi et al., 2013; Simbizi 2016).

Interestingly, serovar Bratislava was reported as the most prevalent serovar in humans in Somalia (Cacciapuoti et al., 1982), Ethiopia's neighbouring country. It was also detected in cattle in Kenya (Ball, 1966). Considering the capacity for horses to act as reservoir hosts for serovar Bratislava (van den Ingh et al., 1989), horses in East Africa may be acting as 
important reservoirs of serovar Bratislava and shedding the organism into the environment contaminating soil and water which becomes the source of infection to other susceptible animals and humans (Hamond et al., 2013). Concurrent findings of high seroprevalence of serovar Bratislava among humans and horses in East Africa suggest that perhaps, by monitoring seroconversion in horses, they may be used as sentinel animals to predict leptospirosis incidences in humans in the region.

Djasiman was the second most reactive serovar among cart horses in Central and Southern Ethiopia. Serovar Djasiman has not been previously described in Ethiopian horses but it has been reported in Australian horses (Wangdi et al., 2013). Serogroup Djasiman has been reported in humans (Biggs et al., 2011).

The serovar Topaz, which is a member of the serogroup Tarssovi, was never previously reported in Ethiopia, however, serovar Tarssovi has been previously detected in cattle in Ethiopia (Moch et al., 1975) and South Africa (Hesterberg et al., 2009). During quantitative MAT of the sera, serovar Tarssovi has showed up repeatedly together with serovar Topaz but at a lower titre. It was therefore eliminated during the adjustment of the MAT results for cross-reactions among different serovars within the same serogroup. Serovar Topaz was not included in the panel of antigens used by Moch et al. (1975). This could mean that it was serovar Tarssovi cross-reacting with serovar Topaz in that study. Serovar Topaz was reported to be the second most predominant serovar affecting horses in Northern Queensland, Australia (Wangdi et al., 2013).

Among the Leptospira serovars detected, serovar Pomona had a seroprevalence of $5.26 \%$. A previous serological survey conducted in domestic and wild animals in Ethiopia detected the presence of the serovar Pomona in cattle (Moch et al., 1975). It is known that cattle and pigs act as maintenance hosts for serovar Pomona (Carpio and Iversen, 1979). Though the 
previous study in Ethiopia did not report it in pigs, which could be due to small sample size, it is possible that cattle and pigs are acting as sources of Pomona infection for horses (Carpio and Iversen, 1979). Other authors have reported a relatively higher seroprevalence of serotype Pomona in horses (Carpio and Iversen, 1979; Barwick et al., 1998) as compared to the current finding. The higher titres found for Pomona (29\% of titres were $1600-3200)$ may indicate a greater susceptibility to infection by this serovar.

\subsection{Sero-prevalence}

This study was not designed as a prevalence study but given that little has been published on the prevalence of leptospirosis in Ethiopia it was decided to report our results as an indication of seroprevalence in Ethiopia. The main weakness of the study as a prevalence study is the non-probability sampling of the population that took place. The survey had to be done in this way because of the difficulty in working within a developing country like Ethiopia and associated security, budgetary and skilled manpower constraints. Consenting owners horses were bled as they arrived at the clinics. These owners had no prior knowledge of the survey before coming to the clinic thus bringing in a degree of randomness. However, there may have been some bias because horses were being brought in for welfare reasons and may thus not have been truly representative of the general population of cart horses. For this reason the prevalence results need to be viewed with some caution but remain the best evaluation of prevalence to date. Our study found that $44 \%$ of horses sampled had antibodies to leptospirosis. The only other published data on leptospirosis in horses in Ethiopia dates back to 1975 and reported a seropositivity rate of $91.3 \%$ in horses (Moch et al., 1975). The variation in seroprevalence between studies could be due to an element of sampling bias in both studies and the fact that Moch et al's study had a much smaller sample size of only 34 horses. The fact remains that high seroprevalence of Leptospira among cart horses, in which 
the majority of titres were low (1:100), suggests that the disease is endemic in horses of Central and Southern Ethiopia.

In this study, the highest seroprevalence of leptospirosis and in particular serovars Bratislava and Djasiman was recorded in horses from the highland agroecology followed by the midland and lowland, respectively. The possible reason for this trend could be the amount of rainfall these agroecologies receive. Districts in the highland generally receive a higher amount of rainfall annually as compared to the districts in the midland and lowland agroecology. This probably contributes to persistence of leptospires in the environment as a result of wet environmental conditions. It has been suggested that high rainfall could provide a suitable environment for leptospires to survive for extended periods ensuring a sustained source of infection for a susceptible host population (Wangdi et al., 2013).

Seroprevalence of leptospirosis varied significantly among districts. Higher seropositivity was detected in the districts of Ziway (Batu), Shashemene and Sebeta for both leptospirosis in general and for serovar Bratislava. The higher seroprevalence in Shashemene and Sebeta could be a reflection of the highland agroecology they are located in. However, the highest prevalence in Ziway (Batu) (lowland) is in striking contrast to the finding that horses from the highland agroecology were at higher risk of being seropositive to serovar Bratislava. The presence of lake Ziway in the vicinity of this district combined with other factors which were not investigated in this study, like animal density and soil characteristics, may have contributed to the high seroprevalence here. Horses in Shashemene were found to be at higher risk of Leptospira exposure than other districts in the logistic regression models with the exception of Ziway (Batu) in the Bratislava model. .

\subsection{Risk Factors}


Risk factors in the overall model differed slightly from the Bratislava model. The presence of papaya plantation was a significant risk factor in the overall model but not the Bratislava model. The reason for this is uncertain, but may have to do with reservoir hosts found in these environments. The number of districts which were significantly associated to the outcome of seropositivity in the overall model was higher $(n=6)$ in the overall model as compared to that of the Bratislava model $(n=2)$ and may be related to the smaller sample sizes in the Bratislava model, which reduced the power in this model.

Something that doesn't appear to have been reported before is the presence of dogs in adjacent neighbouring properties being protective for leptospirosis exposure. Dogs were significantly protective against seropositivity to serovar Bratislava but failed to come up as a risk factor in the overall model. This may be due to the deterrent effect of dogs on rodents, which are associated with serovar Bratislava. It has been suggested that small rodents living in the wild usually invade stables and houses in late summer and autumn, which can give an increased infection incidence during this period (Båverud et al., 2009). The presence of dogs may therefore be deterring the rodents from invading properties thereby reducing the chance of environmental contamination and infection of horses from the environment.

Age, district and the use of river as a source of drinking water were common risk factors in both models indicating that these were the most important risk factors associated with leptospirosis. A possible explanation for river water being a significant risk factor may be due to the water being contaminated by infected urine of horses themselves and other domestic animals including rats since animals and people in Ethiopia have free access to the river and often use it for ablution purposes. Flooding of the rivers during the rainy season may have also contributed. It has been described that leptospirosis should be considered as a significant risk to horses and other animals exposed to flood waters or other contaminated water courses (Hamond et al., 2013). An increasing risk with age is not a new finding and can be explained 
by increased opportunity for exposure with increasing age. Leptospiral antibodies may be detected in days after exposure to Leptospira spp. and may persist for weeks or months or years (OIE, 2015). Different studies conducted to assess the risk factors for exposure to leptospirosis in horses in different parts of the world indicated that flooding, poor sanitation, old age, horse density, housing, exposure to rodents and wild life are associated with increased risk of seropositivity to some serovars (Hines, 2007; Hamond et al., 2014)

\subsection{Clinical signs}

Leptospirosis in horses is often associated with abortion (Shapiro et al., 1999; Timoney et al., 2011) and equine recurrent uveitis (Yan et al., 2010; Turk et al., 2013). However, sporadic cases of renal and hepatic disease have also been reported with associated signs like haematuria, fever, jaundice, anorexia, and respiratory distress (Yan et al., 2010; Broux et al., 2012). Most of the literature has associated these pathological conditions with serovar Pomona (Wangdi et al., 2013), which was detected in the current study. In spite of the consistently higher proportion of seropositive horses showing the occurrence of ocular disease, high fever and yellow discoloration of mucus membranes in the previous year, none of them was significantly associated to seropositivity to serovars Bratislava and Djasiman. This could be because the poor welfare and health condition of these cart horses may have exposed them to other disease conditions with similar syndromes. This further supports the authors' assumption that these serovars may not cause significant clinical disease in horses and particularly serovar Bratislava could already be adapted to horses.

In conclusion, the study shows that horses play an important role in the epidemiology of leptospirosis in Ethiopia and probably other tropical regions of the world as well and their role as potential reservoirs of disease needs to be studied further. 


\section{Acknowledgements}

Funding for this project came from AusAID, Australia, The National Research Foundation, South Africa and James Cook University, Australia. The authors wish to thank the ARC-OVI, South Africa and SPANA Ethiopia and their staff for their assistance with this project.

\section{References}

Admassu, B., Shiferaw, Y., 2011. Donkeys, Horses and Mules: Their Contribution to People's Livelihoods in Ethiopia. The Brooke, London.

Arent, Z.J., Kedzierska-Mieszkowska, S., 2013. Seroprevalence study of leptospirosis in horses in northern Poland. The Veterinary Record 172, 269.

Ayelet, G., Derso, S., Jenberie, S., Tigre, W., Aklilu, N., Gelaye, E., Asmare, K., 2013. Outbreak investigation and molecular characterization of African horse sickness virus circulating in selected areas of Ethiopia. Acta Tropica 127, 91-96.

Ball, M.G., 1966. Animal hosts of leptospires in Kenya and Uganda. The American Journal of Tropical Medicine and Hygiene 15, 523-530.

Barwick, R.S., Mohammed, H.O., McDonough, P.L., White, M.E., 1998. Epidemiologic features of equine Leptospira interrogans of human significance. Preventive Veterinary Medicine 36, 153-165.

Biggs, H.M., Bui, D.M., Galloway, R.L., Stoddard, R.A., Shadomy, S.V., Morrissey, A.B., Bartlett, J.A., Onyango, J.J., Maro, V.P., Kinabo, G.D., 2011. Leptospirosis among hospitalized febrile patients in northern Tanzania. The American Journal of Tropical Medicine and Hygiene 85, 275-281.

Broux, B., Torfs, S., Wegge, B., Deprez, P., Loon, G., 2012. Acute respiratory failure caused by Leptospira spp. in 5 foals. Journal of Veterinary Internal Medicine 26, 684-687. 
Cacciapuoti, B., Nuti, M., Pinto, A., Sabrie, A., 1982. Human leptospirosis in Somalia: a serological survey. Transactions of the Royal Society of Tropical Medicine and Hygiene 76, 178-182.

Carpio, M., Iversen, J., 1979. A serological survey of Leptospira interrogans serotype pomona in Saskatchewan horses. The Canadian Veterinary Journal 20, 127.

CSA, 2013. Agricultural Sample Survey: Report on Livestock and Livestock Characteristics, Statistical Bulletin, 570. Addis Ababa, Ethiopia. In: Authority, C.S. (Ed.), Addis Ababa.

Dinka, H., Shelima, B., Abalti, A., Geleta, T., Mume, T., Chala, R., 2007. Socio-economic importance and management of carthorses in the mid Rift Valley of Ethiopia. Fifth International Colloquium on Working Equines. The future of working equines. Addis Ababa, Ethiopia, 30 October - 2 November 2006, 181-188.

Dohoo, I., Martin, W., Stryhn, H., 2009. Veterinary Epidemiologic Research. 2nd Edtn. Pp385. AVC Inc., Charlottetown, Prince Edward Island, Canada.

Hamond, C., Martins, G., Lawson-Ferreira, R., Medeiros, M., Lilenbaum, W., 2013. The role of horses in the transmission of leptospirosis in an urban tropical area. Epidemiology and Infection 141, 33-35.

Hamond, C., Pinna, A., Martins, G., Lilenbaum, W., 2014. The role of leptospirosis in reproductive disorders in horses. Trop Anim Health Prod 46, 1-10.

Hesterberg, U.W., Bagnall, R., Bosch, B., Perrett, K., Horner, R., Gummow, B. 2009. A serological survey of leptospirosis in cattle of rural communities in the province of Kwa-Zulu Natal, South Africa. Journal of the South African Veterinary Association, $80,45-49$. 
Hines, M.T., 2007. Chapter 34 - Leptospirosis. In: Debra, C.S., Dvm, PhD, Dacvim, Maureen T. Long, D.V.M.P.D. (Eds.), Equine Infectious Diseases. W.B. Saunders, Saint Louis, 301-309.

Hintze, J., 2013. NCSS 9 Statistical Software. NCSS, LLC. Kaysville, Utah, USA, ncss.com/software/ncss.

Katz, M. H., 1999: Multivariable Analysis: A Practical Guide for Clinicians. Cambridge University Press, The Pitt building, Trumpington street, Cambridge United Kingdom.

Kefena, E., Dessie, T., Han, J.L., Kurtu, M.Y., Rosenbom, S., Beja-Pereira, A., 2012. Morphological diversities and ecozones of Ethiopian horse populations. Animal Genetic Resources / Resources Génétiques Animales / Recursos Genéticos Animales $50,1-12$.

Moch, R.W., Ebner, E.E., Barsoum, L.S., Botros, B.A., 1975. Leptospirosis in Ethiopia: a serological survey in domestic and wild animals. The Journal of Tropical Medicine and Hygiene 78, 38-42.

OIE Manual of Diagnostic Tests and Vaccines for Terrestrial Animals, 2014. Chapter 2.1.9 Leptospirosis, http://www.oie.int/international-standard-setting/terrestrialmanual/access-online/ accessed 25-11-2015

Pappas, G., Papadimitriou, P., Siozopoulou, V., Christou, L., Akritidis, N., 2008. The globalization of leptospirosis: worldwide incidence trends. International Journal of Infectious Diseases 12, 351-357.

Pearson, R.A., Krecek, R.C., 2006. Delivery of health and husbandry improvements to working animals in Africa. Trop Anim Health Prod 38, 93-101.

Pearson, R.A., Vall, E., 1998. Performance and management of draught animals in agriculture in sub-Saharan Africa: a review. Tropical Animal Health and Production 30, 309-324. 
Pinna, M., Varges, R., Abreu, R., Lilenbaum, W., 2007. Outbreak of equine leptospirosis by serovar Bratislava. Online Journal of Veterinary Research 11, 1-4.

Shapiro, J.L., Prescott, J.F., Henry, G., 1999. Equine abortions in eastern Ontario due to leptospirosis. The Canadian Veterinary Journal 40, 350.

Simbizi, V., 2016. A study of leptospirosis in South African horses and associated risk factors. Masters Thesis, University of Pretoria, Pretoria, South Africa, under examination

Szeredi, L., Haake, D.A., 2006. Immunohistochemical identification and pathologic findings in natural cases of equine abortion caused by leptospiral infection. Veterinary Pathology Online 43, 755-761.

Tafese, A., Jibat, T., Aklilu, N., Zewdu, H., Kumsa, B., 2013. Lice infesting horses in three agroecological zones in central Oromia. J Parasit Dis, 1-6.

Thrusfield, M., 2007. Veterinary Epidemiology ( $3^{\text {rd }}$ Ed). Wiley-Blackwell Hoboken, NJ, USA.

Timoney, J.F., Kalimuthusamy, N., Velineni, S., Donahue, J.M., Artiushin, S.C., Fettinger, M., 2011. A unique genotype of Leptospira interrogans serovar Pomona type kennewicki is associated with equine abortion. Veterinary Microbiology 150, 349353.

Turk, N., Milas, Z., Habuš, J., Majetić, Z.Š., Perko, V.M., Barbić, L., Stevanović, V., Perharić, M., Starešina, V., 2013. Equine leptospirosis in Croatia - occurrence of subclinical infections and abortions. Veterinarski Arhiv 83, 253-262.

van den Ingh, T., Hartman, E., Bercovich, Z., 1989. Clinical Leptospira interrogans serogroup Australis serovar lora infection in a stud farm in The Netherlands. Veterinary Quarterly 11, 175-182. 
Wangdi, C., Picard, J., Tan, R., Condon, F., Dowling, B., Gummow, B., 2013. Equine leptospirosis in tropical Northern Queensland. Australian Veterinary Journal 91, 190197.

Yan, W., Faisal, S., Divers, T., McDonough, S., Akey, B., Chang, Y.F., 2010. Experimental Leptospira interrogans serovar Kennewicki infection of horses. Journal of Veterinary Internal Medicine 24, 912-917. 